of vital energy, a pulse hurried and feeble, and occasional vomiting of sterconaceous matter, with rather obstinate constipation. Such was her condition at the time I first saw her, now five weeks since, previous to which time she had been under the judicious managenent of my friend $\mathrm{Mr}$. Gardiner, a highly respected practitioner in these towns. I prescribed a laxative cnema, to be used as oucasion might require, with the internal use of a mixtme composed of the Ammon. Carbon. and Conf. Aroin. in campho: julep. With this treatment she ralied somewhat, and $I$ determined on tying the effect of the Potass. Hydriol., under the use of which sise certainly improved; the ablomen from being greatly distended reacqui:ced its natural dimensions, the vomiting ceased, and the bowels beenme more regular. She contimued to prugress apparently wall until within three days of the period of her death (which occurrel on the 2 th of last month), when a profiss diarlhoea came on, under which she sank.

I learnt from her mother that the motions had latterly passed through the ragiua, as well as an anazing quantity of flatus. I was struck on reccivin 5 this intelligence, but seeing that her death was fast approsching, I thought fit to await the issue of a postmortem inspection of the body.

Autopsy. - On opening the abdomen the intostines were found much distended with flatns; there was no fluid in the peritoneum, on examining the small intesine, which for the most part occupisal the brim of the pelvis, there were discovered very numerous alhesions between them, and these again adhered to the omentum, and the peritonoun lining the internal parietes of the abdomen. On separating one very firm adhe. sion existing between the ileun and abdominal parietes, there escaped through an nicerated aperture in the intestine several ounces of seru-purulent fluid, mixed with fecal matter; proceeding on 1 found the uterus much hypertrophied, and its upper and lateral part, near to its fundus, was occupied by a firm adhesion to the caput creci, presenting a fistulons passare between the two organs, of the size of a common writing quill; the fundus uteri was frmly adherent to a portion of ilcum three inches in lengtl, the intestine having a communication to the sarue extent, through a large ulcerated fissure with the cavity of the uterus; the mucous membrane was in a state of sloughy ulceration; the vagina was normal; the rectum and the whole of the colon were filled with hardened feces, as in Mr. Thurnham's case, from which fact the same inference may be drawn. I am, Sir, your obedient servant,

JAS. Gro. DAveY, M.R.C.S.L.

3, Mule End Terrace, Portsea, Hants., May 4, 1836.

\section{RELATIVE QUALITIES OF}

\section{BARK AND QUININE.}

\section{To the Editor of THE LANCET.}

SIR: In No. 659 of THE LANcet there is a report of the proceedings of the Westminster Medical Society, on the 26th of March, wherein I am represented as express. ing iny astonishment, "that Dr. Thomson should say that the great objection to the use of bark was its balk, when a more weighty objection was its frequent adulteration. In the West Indies, where his (my) experience lay, the bark was almost always afulterated, and seemed mixed with something like brick-dust, whereas suiphate of quinine was comparatively pure." Perhaps you will allow me to correct the above statement, by remarking thit my observation was not directed to the adulteration but the deterioration of bark, as effected by the climate, if kept for any length of time, especially when a houtle or parcel of it has once been opened for use; and I added that, if then not speedily used, it became as inert as brick-dust. From such liability to change, sulphate of quinine is free, and on this account very superior to bark. It is very irue that Dr. Webster sair that sulphate of quinine was as liable to aduiteration as bark, and in reply I stated my ignorance of the relative liability to, or the degree of atulteration in, these medicines; but this was a fact, that since the introduction of sulphate of quinize into the West Indies, not only were internittent and remittent fevers more easily, but more permanently cured, and a gentleman sitting by me, who had been in the East Indies, told me that such also was the caso thrre. I am, Sir, your most obedient servant,

\section{P. Ballantixe Fergusson.}

Bath, 26th April, 1836 .

I would observe that my remarks were elicited in consequence of Dr. Thomson having spoken of his experience in Chinn, and though, for my preterence to the sulphate of quinine, the cause assigned has more force in warm climates, yet in a degree it is applicable to all.

\section{IARGE DOSESOF}

\section{EMETIC TARTAR.}

\section{To the Editor of The LanceT.}

SrR: In the last No. of your invaluable journal, to which I have been a subscriber from its coumencement, I observed a case of delirium tremens, which appears to have been treated with such large doses of Antim. Tartariz, and so frequently repeated, that I 
consider the patient fortunate in having escaped its poisonous effects. However, it is probable that a considerable portion of the preparation never entered the stomach. If your correspondent will take the trouble to refer to Beck, or any other author on forensic medicine, he will find that cases of poison are on record where less quantities of emetic tartar than he prescribed to his patient had been swallowed. In No. 76 of the Edin. burgh Medical and Surgical Journal, which periodical it would appear your correspondent is in the habit of perising, a case is related where a physician by mistake swallowed from twenty to twenty-fire graius Ant. Tartar., and, although in combination with carbonate of soda, a considerable period elapsed bofore he perfectly recovered from it 3 effects. Perhaps your correspondent will be kind enough to explain the modus operandi of the remedy (?) which he employed. In justification of this treatment he may say that there is great morbid insensibility (rather fortunate in his case) of the stomach ; but even granting that, would not the effects usually produced by the administration of mineral poisons be likcly to result in similar cases to the one he has reported?

In conclusion I will quote the words of Dr. Copland (whose "Dictionary of Practi. cal Medicine" I would particularly recommend to his notice), when speaking of the large doses of medicines which sometimes are prescribed in this affection:"Feats of hardihood in medicine are too often the consequence of clinical and practical ignorance, and they may be allowed to meet their own rewards, so long as they are not obtruded in to the annals of our science, and thereby set forth to the inexperiencerl as examples to be followed \&c." I am, Sir, your constant reader and well.wisher,

Poplar, April 27th, 1836.

$$
\text { G. BuRrow. }
$$

\section{SELF-CASTRATION.}

\section{To the Editor of THE LANCET.}

Str: I have read the rcmarks of you correspondent in The Lancet of April 23, on the case of Morgan in St. George's Hospital. I saw the man very shortly after the mischief, and he was perfectly cool and collected, indeed he was so cool as to have wrapped up the excised parts in an old handkerchief, and placed them in his pocket. I could scarcely credit the fact until I saw the scrotum and testicles, and which at "one fell swoop" of the razor he had excised most adroitly, by placing a piece of cord tightly round near the base of the penis. He was much exhausted by loss of blood and want of nourishment, and $I$ expected every pulsation would have been his last. A little brandy and water, with occasional renewal of the stimulus, aroused him, and I thought it better, as he was houseless, to send hin at once to the hospital. The syncope was so great at the outset, that I had felt disposed to allow the handkerchief which he had pressed upon the wouniled parts to remain, as the clotted blood effectually stopped the mouths of the vessels, and temporarly re. strained hemorrhage. However, the paro. chial surgeon came, and, upon consideration, it was thought better to tie the vessels, and, most fortunately for the man, it was readly accomplished without much loss of blood; a few more ounces lost, and the equilibriun had been destroyed. No one could have been more attentive than the parochial sur. geon (Mr. Martin), for, fearing any second. ary hemorrhage, he went up himself with the man to the hospital, and then left him safe. It appears that Morgan had been allowell to go out on Easter Monday, and that he came home half intoxicated. There wass a patient (a young yirl) in the workhouse, half idiotic, or, which is more likely, trotbled with nymphomania. She went into the man's room, and the temptation orer. came him. He has beerr, however, a very troublesome man, but it would have been more advisalle to have dealt with him le. gally. A man guilty of murder, in Newgate is housed and fed, and, how ever heinous the crime, it should never be forgotten that the malefactor has a stomach, and that the gastric juice is an unpleasant secretion, unless it have somewhat to act upon. If the man recovers (and I saw him doing well on Saturday), the operation for castration is a mightily simple one. Yours very faithfully, Thomas Litchfield.

Twickenham, April 27, 1836.

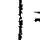

The Phylsiology of Digestion, considered with relation to the Principles of Dietetics. By Axdrew Combe, M. D., Edinburgh. Maclachlan, 1836. London. Simpkin. pp. 332.

Dr. Conse has rightly considered the favourable reception which his "Principles of Physiology Applied to the Preservation of Health" obtained, as a proof of gond ap. petite in the reading public, whose pro. bable hunger after more food prepared by the same hand he has therefore here at. tempted to satisfy, according to promise expressed in the preface to his former supply. The medical writings by which $\mathrm{Dr}$. Combe is best and most generally known, ure characterized by perspicuous views of he structure and functions of the body, well adapted for the comprehension of non-professional readers, anid at the same timeso 